
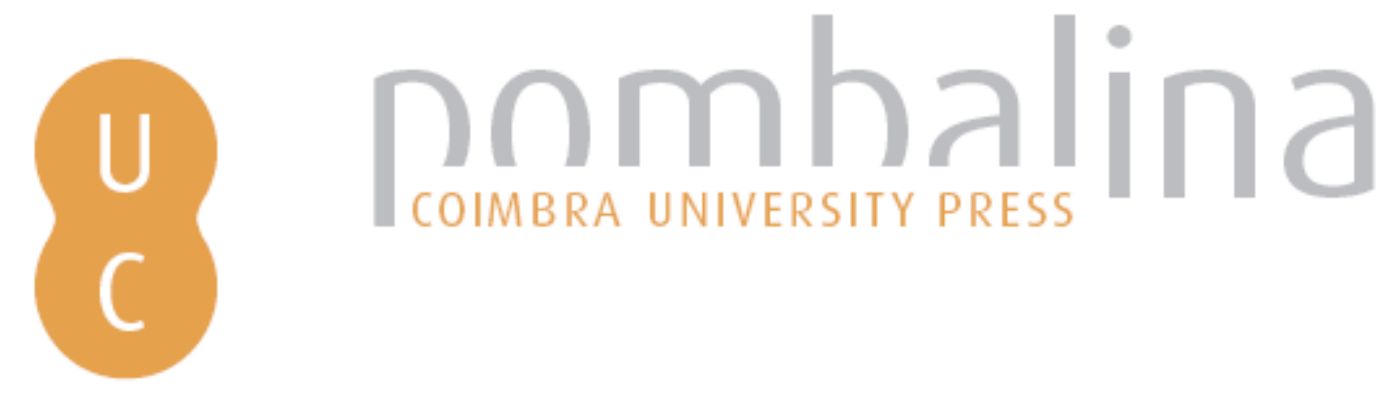

\title{
A numerical study of crown fires spread using a conjugate formulation
}

\author{
Autor(es): Perminov, Valeriy
}

Publicado por: Imprensa da Universidade de Coimbra

URL

persistente: URI:http://hdl.handle.net/10316.2/34020

DOI: $\quad$ DOI:http://dx.doi.org/10.14195/978-989-26-0884-6_3

Accessed : $\quad$ 26-Apr-2023 00:26:04

A navegação consulta e descarregamento dos títulos inseridos nas Bibliotecas Digitais UC Digitalis, UC Pombalina e UC Impactum, pressupõem a aceitação plena e sem reservas dos Termos e Condições de Uso destas Bibliotecas Digitais, disponíveis em https://digitalis.uc.pt/pt-pt/termos.

Conforme exposto nos referidos Termos e Condições de Uso, o descarregamento de títulos de acesso restrito requer uma licença válida de autorização devendo o utilizador aceder ao(s) documento(s) a partir de um endereço de IP da instituição detentora da supramencionada licença.

Ao utilizador é apenas permitido o descarregamento para uso pessoal, pelo que o emprego do(s) título(s) descarregado(s) para outro fim, designadamente comercial, carece de autorização do respetivo autor ou editor da obra.

Na medida em que todas as obras da UC Digitalis se encontram protegidas pelo Código do Direito de Autor e Direitos Conexos e demais legislação aplicável, toda a cópia, parcial ou total, deste documento, nos casos em que é legalmente admitida, deverá conter ou fazer-se acompanhar por este aviso.

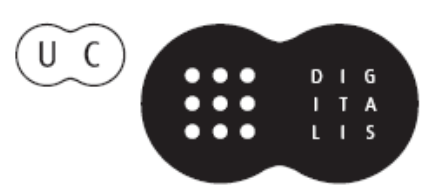




\section{ADVANCES IN}

Forest Fire

\section{RESEARCH}

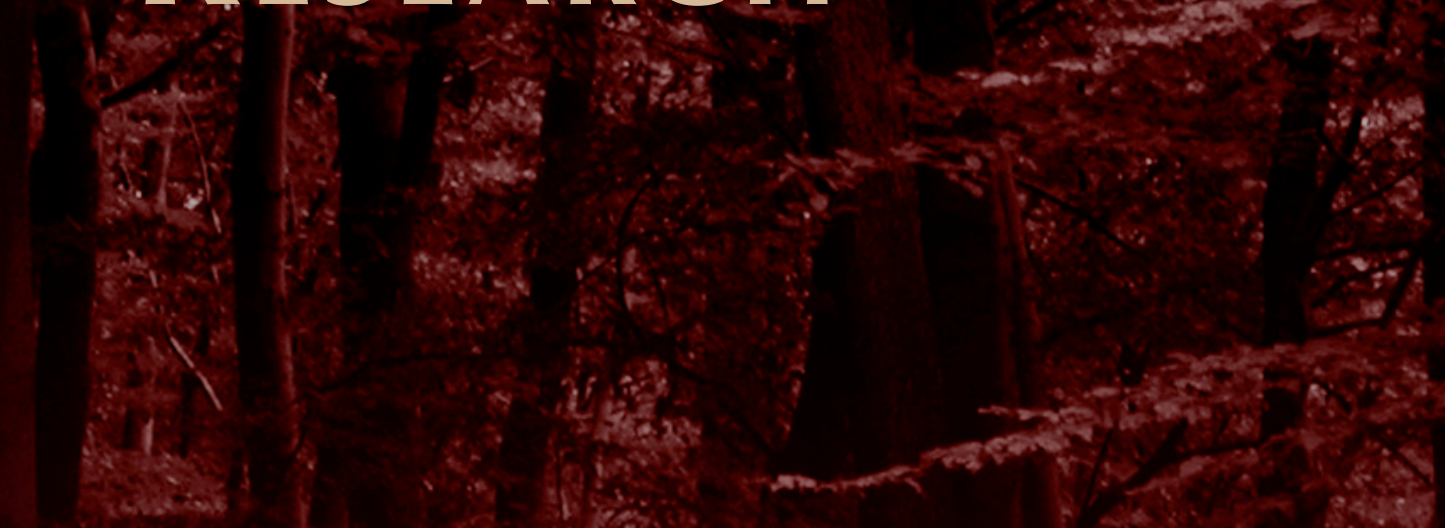

\section{DOMINGOS XAVIER VIEGAS}

\section{EDITOR}




\title{
A numerical study of crown fires spread using a conjugate formulation
}

\author{
Valeriy Perminov \\ Tomsk Polytechnic University, Russia 634050, Lenin Avenue, 30, valerperminov@ gmail.com
}

\begin{abstract}
The aim of the present paper is to study the behaviour of crown forest fires propagating through crown canopy and to study the mutual influence of crown forest fires and boundary layer of atmosphere using numerical simulation with a physics-based model. It is a coupled atmosphere/crown fire behavior model and is based on conservation of mass, momentum, species and energy. The boundary-value problem is solved numerically using the method of splitting according to physical processes. It allows investigating dynamics of forest fire initiation and spreading under influence of various external conditions: a) meteorology conditions (air temperature, wind velocity etc.), b) type (various kinds of forest combustible materials) and their state (load, moisture etc.).
\end{abstract}

Keywords: forest fire, mathematical modelling, control volume, numerical solution

\section{Introduction}

Fires spreading in crowns are often more intense than fires spreading through surface vegetation. As a result, they are more difficult to suppress, produce higher heat fluxes and more smoke. They can interact with boundary layer of atmosphere that leads to dangerous fire behaviour. The end goal is to develop a range of computationally efficient tools to help land managers and others assess forest fire risk to communities and homes. A suitably validated physics-based approach has the potential to account for realistic variations in the environmental. Considering that, natural investigations of these problems are merely impossible, methods of mathematical modelling are urgent.

\section{Physical and mathematical model}

Considering domain consist of two parts: boundary layer of atmosphere and forest. Let us examine a plane problem of radiation-convection heat and mass exchange of forest fuels in all forest strata with gaseous combustion products and radiation from the tongue of flame of the crown forest fire The fire source is modeled as a plane layer of burning forest fuels with known temperature and increasing area of burning. It is assumed that the forest during a forest fire can be modeled as a homogeneous twotemperature multiphase non-deformable porous reactive medium [1]. Temperatures of condensed and gaseous phases are separated out. The first includes a dry organic substance, moisture (water in the liquid-drop state), condensed pyrolysis and combustion products (coke, ash) and mineral part of forest fuels. In the gaseous phase it is separated out only the components necessary to describe reactions of combustion (oxygen, combustible products of pyrolysis of forest fuels and the rest inert components). Let the coordinate reference point $x_{1}, x_{2}=0$ be situated at the centre of the forest fire source at the height of the roughness level, axis $0 x_{2}$ directed upward, axis $0 x_{1}$ directed parallel to the Earth's surface to the right in the direction of the unperturbed wind speed (Fig.1). 


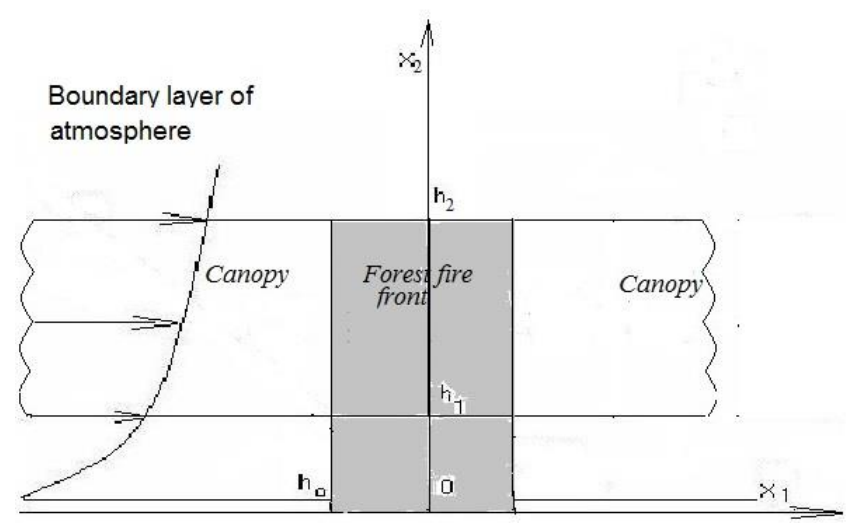

Figure 1. Scheme of the domain

The problem formulated above is reduced to a solution of the system of equations (1)-(6):

$$
\begin{aligned}
& \frac{\partial \rho}{\partial t}+\frac{\partial}{\partial x_{j}}\left(\rho v_{j}\right)=\dot{m}, j=1,2, i=1,2 ; \\
& \rho \frac{d v_{i}}{d t}=-\frac{\partial P}{\partial x_{i}}+\frac{\partial}{\partial x_{j}}\left(-\rho \vec{v}_{i}^{\prime} \vec{v}_{j}^{\prime}\right)-\rho s c_{d} v_{i}|\vec{v}|-\rho g_{i}-\dot{m} v_{i} ; \\
& \rho c_{p} \frac{d T}{d t}=\frac{\partial}{\partial x_{j}}\left(-\rho c_{p} \overline{\left.v_{j}^{\prime} T^{\prime}\right)}+q_{5} R_{5}-\alpha_{v}\left(T-T_{S}\right)+k_{g}\left(c U_{R}-4 \sigma T^{4}\right) ;\right. \\
& \rho \frac{d c_{\alpha}}{\partial t}=\frac{\partial}{\partial x_{j}}\left(-\rho \overline{v_{j}^{\prime} c_{\alpha}^{\prime}}\right)+R_{5 \alpha}-\dot{m} c_{\alpha}, \alpha=1, \ldots, 5 ; \\
& \frac{\partial}{\partial x_{j}}\left(\frac{c}{3 k} \frac{\partial U_{R}}{\partial x_{j}}\right)-\left(k+k_{s}\right) c U_{R}+4 \sigma\left(k_{g} T^{4}+k_{s} T_{s}^{4}\right)=0 ; \\
& \sum_{i=1}^{4} \rho_{i} c_{p i} \varphi_{i} \frac{\partial T_{S}}{\partial t}=q_{3} R_{3}-q_{2} R_{2}-k_{S}\left(c U_{R}-4 \sigma T_{S}^{4}\right)+\alpha_{V}\left(T-T_{S}\right) ; \\
& \rho_{1} \frac{\partial \varphi_{1}}{\partial t}=-R_{1}, \rho_{2} \frac{\partial \varphi_{2}}{\partial t}=-R_{2}, \rho_{3} \frac{\partial \varphi_{3}}{\partial t}=\alpha_{c} R_{1}-\frac{M_{c}}{M_{1}} R_{3}, \rho_{4} \frac{\partial \varphi_{4}}{\partial t}=0 ; \\
& \sum_{\alpha=1}^{5} c_{\alpha}=1, P_{e}=\rho R T \sum_{\alpha=1}^{5} \frac{c_{\alpha}}{M_{\alpha}}, \vec{v}=\left(v_{1}, v_{2}\right), \vec{g}=(0, g) .
\end{aligned}
$$

The system of equations (1)-(8) must be solved taking into account the following initial and boundary conditions:

$$
\begin{aligned}
& t=0: v_{1}=0, v_{2}=0, T=T_{e}, c_{\alpha}=c_{\alpha e}, T_{s}=T_{e}, \varphi_{i}=\varphi_{i e} \\
& x_{1}=-x_{1 e}: v_{1}=V_{e}, v_{2}=0, T=T_{e}, c_{\alpha}=c_{\alpha e},-\frac{c}{3 k} \frac{\partial U_{R}}{\partial x_{1}}+c U_{R} / 2=0 \\
& x_{1}=x_{1 e}: \frac{\partial v_{1}}{\partial x_{1}}=0, \frac{\partial v_{2}}{\partial x_{1}}=0, \frac{\partial T}{\partial x_{1}}=0, \frac{\partial c_{\alpha}}{\partial x_{1}}=0, \frac{c}{3 k} \frac{\partial U_{R}}{\partial x_{1}}+c U_{R} / 2=0 ;
\end{aligned}
$$




$$
\begin{gathered}
x_{2}=0: v_{1}=0,\left(\rho v_{2}\right)_{0}=h_{0} \dot{m}_{0}, T=\left\{\begin{array}{l}
T_{e}+\left(T_{0}-T_{e}\right) \exp \left(-\left(\left(x_{1}-x_{10}\right) / \Delta\right)^{2}\right) t / t_{0}, t \leq t_{0} \\
T_{e}+\left(T_{0}-T_{e}\right) \exp \left(-\left(\left(x_{1}-x_{f}\right) / \Delta\right)^{2}\right), \quad t>t_{0}
\end{array},\right. \\
x_{f}=\omega\left(t-t_{0}\right),
\end{gathered}
$$

Here and above $\frac{\mathrm{d}}{\mathrm{d} t}$ is the symbol of the total (substantial) derivative; $\alpha_{v}$ is the coefficient of gas exchange; $t$ is time; $x_{i}, v_{i},(i=1,2)$ are the Cartesian coordinates and the velocity components; $x_{f}$ is a right boundary coordinate of the surface forest fire source in a wind direction; $k_{0}$ is the radiation absorption coefficient in the ground cover, $h_{0}$ is the thickness layer in the ground cover; $\Delta=\Delta_{0}+2 \omega t$ is the size of the surface fire source, $\Delta_{0}$ is the initial value of the characteristic size, $\omega$ is the normal rate of surface fire spread, $t_{0}$ is the time of fire source formation (characteristic time of setting the maximum temperature in the source or the time of ignition), $T_{0}$ and $T_{e}$ are the maximum temperature in the surface fire source and the ambient temperature; index $\alpha=1,2, \ldots, 5$, where 1 corresponds to the density of oxygen, 2 - to carbon monoxide $C O, 3$ - to carbon dioxide and inert components of air, 4 to particles of black, 5 - to particles of smoke. The thermodynamic, thermophysical and structural characteristics correspond to the forest fuels in the canopy of a pine forest [1].

It should be noted that this system of equations describes processes of transfer within the entire region, which includes boundary layer of atmosphere and forest: crown and the space between the underlying surface and the base of the forest canopy. Because of the characteristic sizes of problem for boundary layer of atmosphere and forest are different; it may be more convenient to divide our domain into two parts. Therefore we can solve this problem using a conjugate formulation. Besides for the second domain the horizontal sizes of forest massif more than height of forest, system of equations of general mathematical model of forest fire was integrated between the limits from height of the roughness level - 0 to top boundary of forest crown. Thus the solution of this problem is reduced to the integration of two systems of differential equations taking into account the correspondence initial and boundary conditions (8)-(12) and condition of conjugation between two domains [1].

\section{Method solution and results}

The boundary-value problem is solved numerically using the method of splitting according to physical processes. In the first stage, the hydrodynamic pattern of flow and distribution of scalar functions was calculated. The system of ordinary differential equations of chemical kinetics obtained as a result of splitting was then integrated. A discrete analogue was obtained by means of the control volume method using the SIMPLE like algorithm [2]. Fields of temperature, velocity, component mass fractions, and volume fractions of phases were obtained numerically. At $V_{e} \neq 0$, the wind field in the forest canopy interacts with the gas-jet obstacle that forms from the forest fire source and from the ignited forest canopy and burn away in the forest canopy. The isotherms of gas phase components moved in the forest canopy by the action of wind. It is concluded that the forest fire begins to spread. The results of the calculation give an opportunity to consider forest fire spread for different wind velocity, canopy bulk densities and moisture forest fuel. Figures 2 a, $b$ present the distribution of temperature of gas phase above the crown $\bar{T}\left(\bar{T}=T / T_{e}, T_{e}=300 K\right)\left(1-2 ., 2-2.5,3-3,4-4 ., 5-5\right.$.) for wind velocity $V_{e}=$ $5 \mathrm{~m} / \mathrm{s}$ in different instants of time: I - $t=13 \mathrm{sec}$., II $-t=16 \mathrm{sec}$, III $-t=20 \mathrm{sec}$., IV $-t=23 \mathrm{sec}$ and $V-25$ 
sec. (Fig.2a) and $10 \mathrm{~m} / \mathrm{s}$ (Fig.2b) (I - $t=9$ sec., II $-t=11 \mathrm{sec}$, III $-t=13.5 \mathrm{sec}$., IV $-t=15.5 \mathrm{sec}$.). The distribution of velocity fields is presented also (Fig.3a,b).
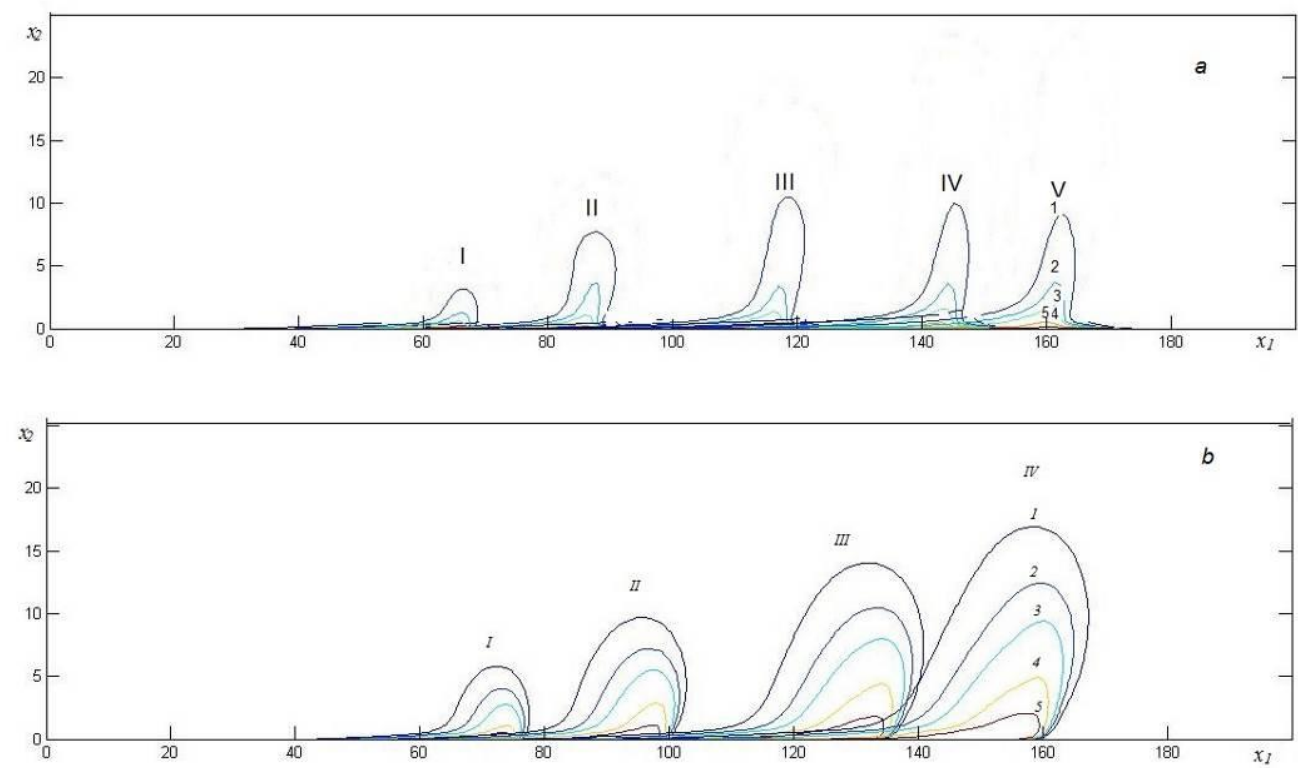

Figure 2. . Field of isotherms of the forest fire spread (gas phase).
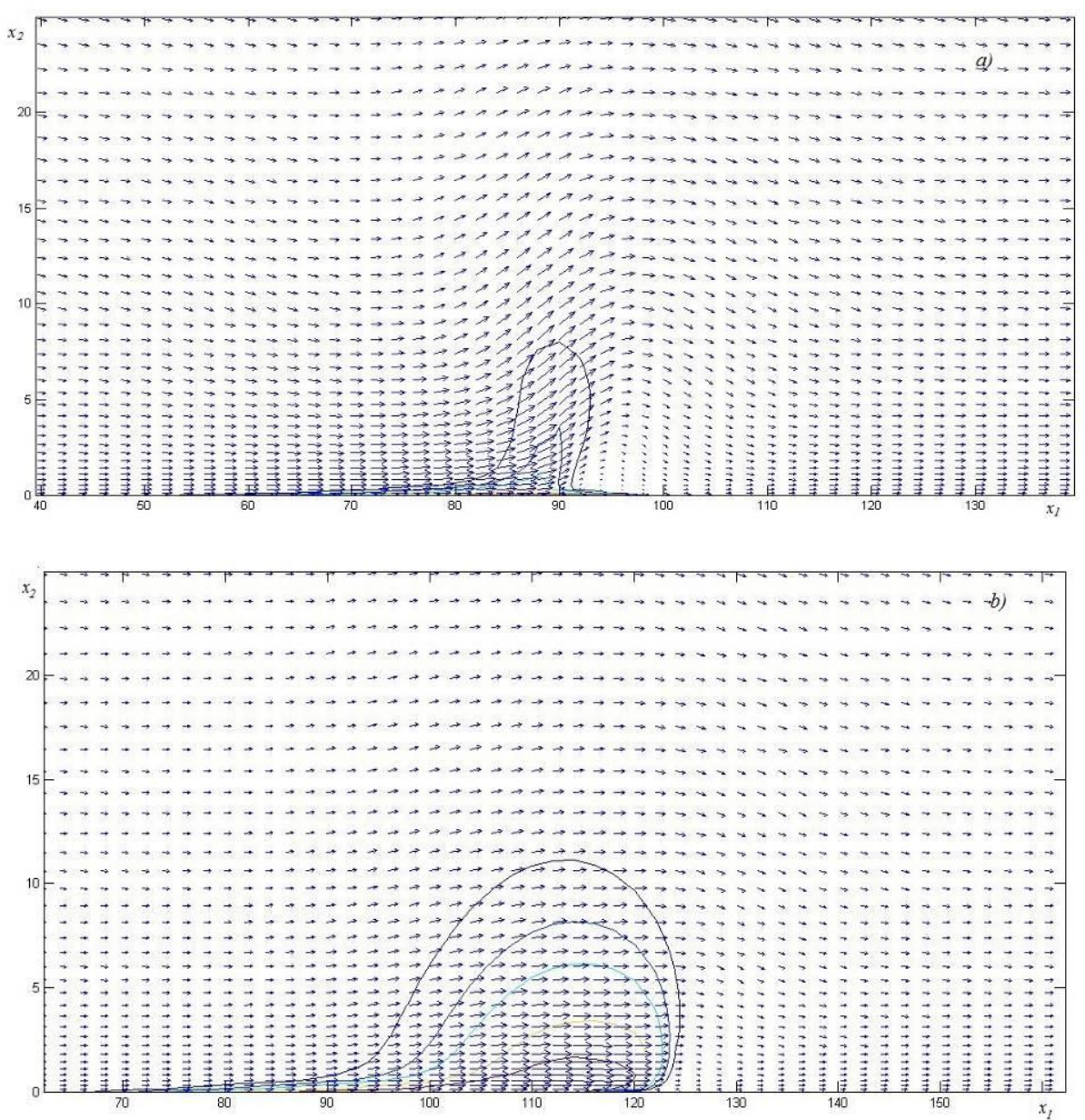

Figure 3- . Fields of velocities for wind: $a) V_{e .}=5 \mathrm{~m} / \mathrm{s}(t=16 \mathrm{~s})$ and $\left.b\right) V_{e}=10 \mathrm{~m} / \mathrm{s}(t=10 \mathrm{~s})$. 
Figures $3 \mathrm{a}$ and $\mathrm{b}$ represent vector fields of velocities and isotherms for different instants of time when a wind velocity $V_{e}=5 \mathrm{~m} / \mathrm{s}$ at a height $x_{2}=10 \mathrm{~m}$ (Fig. 3a) and . It is seen that the effect of the wind results in the tongue of flame defection from the vertical. The wind field above the forest fire front interacts with the gas-jet obstacle that forms from the crown forest fire source. Recirculating flow forms beyond the zone of heat and mass release (Fig.3a), while on the windward side the movement of the air flowing past the ignition region accelerates. But in the second case there is no recirculation flow, because a strong wind destroys it (Fig.3b).

\section{Conclusion}

Results of calculation give an opportunity to describe the different conditions of the crown forest fires spread taking account different weather conditions, state of forest combustible materials, which allows applying the given model for prediction and preventing fires. It overestimates the rate of crown forest fire spread that depends on crown properties: bulk density, moisture content of forest fuel, wind velocity and the influence of boundary layer of atmosphere. The model proposed here gives a detailed picture of the change in the temperature and component concentration fields with time, and determine as well as the influence of different conditions on the crown forest fire spreading for the different cases of inhomogeneous of distribution of sources of forest fires initiation. The results of calculation of the rate of crown forest fires are agreed with the laws of physics and experimental data

\section{References}

1. Grishin A.M., Mathematical Modeling Forest Fire and New Methods Fighting Them, Tomsk: Publishing House of Tomsk University (Russia), 1997.

2. Patankar S.V., Numerical Heat Transfer and Fluid Flow. New York, Hemisphere Publishing Corporation, 1981. 